\title{
3. Finkelstein Report: Volume of media vitriol in inverse proportion to amount of evidence
}

\section{COMMINIIARY}

After all the overheated rhetoric over the Finkelstein Report, it may be an anti-climax to know that the key issue is the right of reply, or the right of redress, to those who feel they have been misrepresented in the news. Such processes are now done through self-regulation by the Australian Press Council, while the Finkelstein Report sees this as insufficiently effective and recommends a government-funded statutory agency.

Keywords: accountability, censorship, corruption, ethics, media regulation, media self-regulation, press councils, statutory bodies

RODNEY TIFFEN

University of Sydney

W

ILD CLAIMS that the Finkelstein Report (2012) recommendations on media regulation increase the threat of government censorship are wrong. Naomi Wolf has called the Finkelstein Report on the press 'step one to fascism'. The former chairman of News Limited, John Hartigan, saw it as part of a jihad against that company. The Australian Financial Review thought it constituted a Labor plan to control the media.

Other commentators took a similar line. John Roskam, of the Institute of Public Affairs, thought it overturned two centuries of Western political philosophy, and was totalitarian. The Sydney Morning Herald said the futility of its approach collapsed with the Berlin Wall in 1989. The Australian's Paul Kelly thought it another threat to freedom in Australia, and that it reflected naive hubris. Bob Cronin, group editor-in-chief of West Australian Newspapers, described it as the most outrageous assault on our democracy in the history of the media, and likened its proposals to what was common when Joe Stalin was running the Soviet Union. 


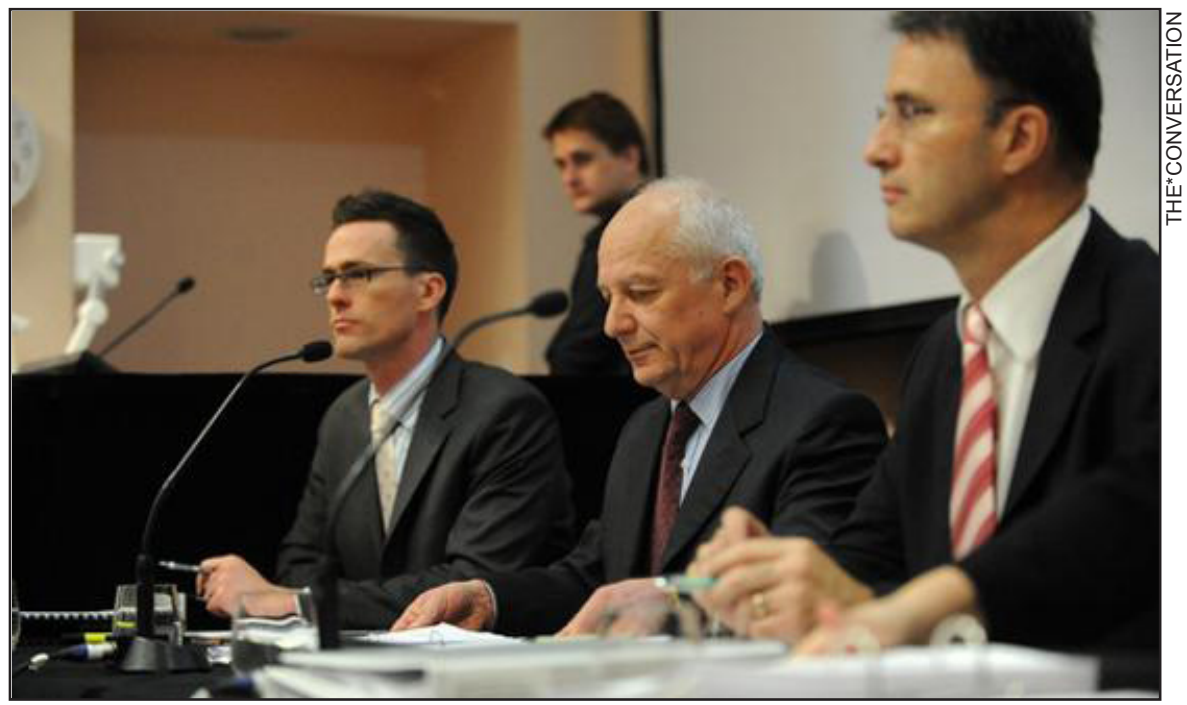

Existing press councils ... 'a system of accountability where those being held accountable can walk away or threaten to reduce funding whenever they wish is by nature very weak'.

While the commentary has been extravagant, the actual reporting of the report's contents was not extensive. Indeed, it followed a common path in contemporary Australian political controversy: the volume of vitriol is in inverse proportion to the amount of evidence.

After all the overheated rhetoric, it may be an anti-climax to know that the key issue is the right of reply, or the right of redress, to those who feel they have been misrepresented in the news. Such processes are now done through self-regulation by the Australian Press Council, while the Finkelstein report sees this as insufficiently effective and recommends a government-funded statutory agency.

In Finkelstein's proposal, the government's role would be limited to providing the funding and legislative framework. The composition of the News Media Council would be identical to the current Press Council's: half from the industry, half from the public, and an independent chair.

As the executive summary states, its standards would be essentially the same as the current Press Council's - not more stringent or restrictive, as some seem to believe. Moreover, the process would also be similar. The outcome-if a complaint went to adjudication and was not settled by conciliation-would be a statement published about the case. 
Both systems share a process whereby complainants give up the right to pursue other legal remedies. Both seek to institute a corrections process that removes financial and legal risks from both parties and resolves complaints in a way that increases rather than restricts public knowledge.

So a body with a similar composition to the Press Council, following similar guidelines, would adopt a similar process with similar outcomes. So why not just keep the Press Council? One reason is that the council, relying on publishers' support, has never been adequately or securely funded.

Its current chairman, like his two predecessors, thinks the council is chronically under-funded and so cannot achieve its goals. It is just a few years since News Limited cut its funding substantially because it disapproved of a Press Council project.

A second reason is that a system of accountability where those being held accountable can walk away or threaten to reduce funding whenever they wish is by nature very weak. It is why Kerry Packer and countless others have called the Press Council a toothless tiger.

It is fitting that as this Australian debate takes place, the British Press Complaints Commission has been dissolved in disgrace. Like its predecessors, it was very much a publishers' poodle. When serious wrong-doing by the News of the World was exposed, it simply defended the paper until the scandal overwhelmed everyone's defences. It is not yet clear what will replace the commission, although it may be a statutory authority.

The controversial aspect of the Finkelstein proposal is that these inherent weaknesses of the Press Council mean there is a need for government involvement. This produces a reflex response among many that either censorship or corruption must follow. It should be remembered that all Australian TV and radio stations are publicly licensed but are obviously vigorous and independent, while the public broadcaster, the $\mathrm{ABC}$, consistently ranks as the most trusted media organisation in the country.

The sharpest conflict comes because, under the new proposal, publishers would not be able to opt out as they choose, but instead would have to publish the council's findings. Also, the idea is that they would publish them in a regular agreed place in the paper so that adverse findings would not be buried.

So two centuries of Western thought comes down to this - the right of editors to withhold from their readers the knowledge of an unwelcome adjudication on one of their stories by their peers and public according to standards they all profess to hold. 
The proposal is an attempt to make the media more accountable to their readers and those covered in the news. It does not increase the power of government to censor or restrict the media in any way. It seeks to conciliate and resolve disputes about news coverage in ways that further the free flow and exchange of information rather than restricting it.

Dr Rodney Tiffen is an emeritus professor of government and international relations at Sydney University and worked on the Finkelstein media inquiry. This article was first published in The Sydney Morning Herald under the title 'Finkelstein gets a bad press' on 14 March 2012.

r.tiffen@econ.usyd.edu.au

\section{Reference:}

Finkelstein, R. (2012). Report of the independent inquiry into the media and media regulation. Report to the Minister for Broadband, Communications and the Digital Economy, 28 February 2012.

\section{PACIFIC MEDIA CENTRE}

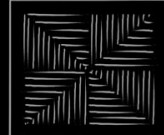

PAFIFIE

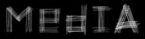
EENTRE TE AMOKURA

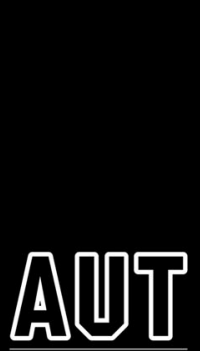

U N I VER S I T Y
The Pacific Media Centre (Te Amokura) is the only media research and community resource centre of its kind in Aotearoa/New Zealand and has a strategic focus on Māori, Pasifika and diversity media and community development:It was established by AUT University's Faculty of Design and Creative Technologies in 2007. having evolved from a cluster of research and community collaborations within the School of Communication Studies.

PMC activities include:

- International book and research publication

- Publication of the peer-reviewed Pacificlournalism Reviewresearch journal

- Publication of Pacific Media Centre Online as a media resource and postgraduate outlet

- Publication of Pacific Media Watch, a regional media monitoring service

- Journalism and media research opportunities

- Asia-Pacific internships for postgraduate students

www.pmc.aut.ac.nz | pmc国aut.ac.nz 
Copyright of Pacific Journalism Review is the property of Auckland University of Technology and its content may not be copied or emailed to multiple sites or posted to a listserv without the copyright holder's express written permission. However, users may print, download, or email articles for individual use.

http://www.aut.ac.nz/depts/commstud/journ/pjrsubs.shtml 